Where Reds are numerous they are very destructive, indeed when looking for telegraph poles during the war it was found that large numbers of trees had been made useless. The damage done by Reds is girdling, and consequent death and malformation of stems, also the destruction of cones and hindrance to natural regeneration.

In my opinion the Red Squirrel will again increase as the new conifer forests grow to cone-bearing age. As in the past, it will be necessary to keep populations in check if widespread damage is to be avoided. I am not among those who think the Grey will clash with the Red except in hardwood areas, nor do I think there is danger of either becoming extinct."

Finally, perhaps, we may quote from Captain Diver's summing up of the situation :-

"Looking at Great Britain as a whole there does not appear to be cause for alarm ; nor is there evidence that such action as the Forestry Commission must take to protect the nation's timber crops against the growth of large populations of the Red Squirrel in the State forests, is dangerous to the continued existence of the species in this country.

If extinction were threatened, the Conservancy would certainly bring their influence to bear to avert it; and I feel sure they would get all reasonable support from the Commission."

\title{
THE PRESENT STATE OF WILD LIFE CONSERVATION IN THE UNION OF SOUTH AFRICA
}

\section{(From the Director of Information, South Africa House)}

Apart from sixty-one Forest Nature Reserves, with a total area of $12,906.7$ acres, the following national parks and nature reserves exist in the Union of South Africa :-

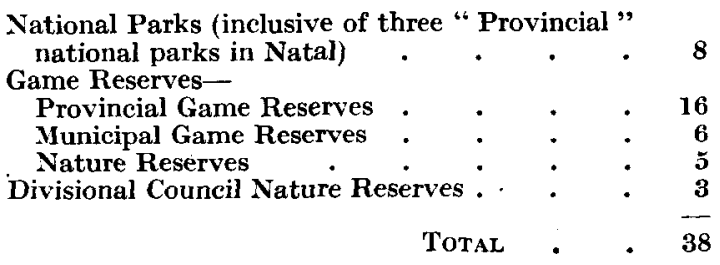


The area covered by these thirty-eight national parks and reserves is approximately $8 \frac{1}{4}$ million acres, or 13,000 square miles. As a nation, therefore, the South Africans have no reason to be ashamed of the provision that has been made by means of national parks and reserves for the country's fauna and flora.

When the post of Warden of the Kruger National Park became vacant towards the end of the year 1945, a statement was issued by a number of South African scientists drawing attention to the fact that the new Warden would have to have scientific qualifications in addition to the other necessary qualifications. For some years several South African scientists were emphasizing the point that neither the Kruger National Park nor any other national park could be successfully administered without the necessary scientific advice and control--in fact, the problems of such parks were in the first place scientific problems that had to be investigated by zoologists, botanists, ecologists, and the like.

Scientists have also been pleading for years that one or two scientists should be appointed to the National Parks Board of Trustees, and in September, 1949, the first appointment of a scientist to the Board was made by Mr. J. G. Strydom, Minister of Lands in the present National Party Government.

Scientific societies and individuals have long been urging that the Union Government should appoint a body of scientists to advise it on matters pertaining to national parks and nature reserves, and on the 1st January, 1949, the Minister of Lands established the Scientific Advisory Council for National Parks and Nature Reserves. Although the former Government had set the ball rolling, nothing had been accomplished.

Each province in the Union has its game legislation, which makes provision for the protection of various species and permits the shooting of some kinds under permit during limited periods of the year. The recent game ordinance passed by the Transvaal Provincial Council has been acclaimed as one of the best game laws in existence. It lays down severe penalties for poaching, illegal shooting, snaring, shooting with spotlights at night time, and the like, and controls the importation and exportation of game products. A court may even order the confiscation of weapons and motor vehicles. A Fauna and Flora Department was established in the Transvaal in the year 1947, and this department works in collaboration with the South African Police to enforce the provisions of the game ordinance. Additional patrols have operated during game seasons with great success.

In the Union of South Africa most of the large game animals 
surviving beyond the boundaries of the national parks and reserves occur in the Transvaal Province. In this province, and in the Union generally, two classes of poachers have to be dealt with, namely European and non-European. The methods of the native poacher are much the more insidious, since he relies largely upon wire snares by which game animals often come to a painful end.

It is not generally realized in Europe that, with a few insignificant exceptions, the native inhabitants of South Africa are to-day in a stage of civilization equivalent to that of Europe 1,500 or 2,000 years ago. To a native a wild antelope is of practically no interest except as a potential source of meat. Along the borders of national parks and reserves, natives will spare no effort to try to capture wild animals by any means at their disposal. After almost three centuries of European settlement in the south of the Union, and less than a century and a quarter of settlement in the Transvaal, the attitude of the natives towards wild life remains essentially the same as it was when the European settlers first landed at the Cape in $\mathbf{1 6 5 2 .}$ It will take many centuries of education to bring about a change of this attitude.

There are areas in the Eastern Transvaal where up to 100 snares have been found around a water-hole. Such areas are now being patrolled by native rangers, with the result that sums of up to about $\mathfrak{£ 3 0 0}$ per month have been collected from fines imposed on poachers. As the result of the convictions attained from more efficient patrolling, a deterrent effect is being noticed. The traffic on roads formerly much used by poachers has dropped to about 50 per cent. In comparison with the year 1947, it is believed that poaching in the Transvaal has decreased by about 60 per cent. This is largely due to the fact that patrolling is now done throughout the year.

At present the staff of the Fauna and Flora Department of the Transvaal Provincial Administration consists, among others, of six scientifically trained persons, four technical assistants, twelve European rangers, Native rangers, and about 200 honorary officials.

Since the Fauna and Flora Department has been established in the Transvaal Province the demand for game animals for restocking farms has grown to such an extent that the Provincial Administration has acquired two farms, one in the High Veld and another in the Low Veld, where it is proposed to breed antelopes. At Panfontein, near Bloemhof, research will be carried out into wild life problems, and suitable dogs will also 
be bred for the destruction of jackals. Panfontein is probably the first wild life research and experimental farm of its kind.

Societies like the Transvaal Hunters' Association, angling societies, farmers' associations, and the like are co-operating with the Transvaal Provincial Administration with a view to achieving more effective conservation. Whereas no funds were available prior to the year 1948 for protection of the Province's wild life, the Transvaal Provincial Administration's present budget for that purpose and the stocking of the Province's water with fish amounts to nearly $£ 100,000$. What is believed to be the largest hatchery in Africa is at present being built at Lydenburg. A board, the Fauna and Flora Advisory Board, has been established to advise the Province on all matters pertaining to wild life conservation in the Transvaal.

A very important provision in the new Game Ordinance of Transvaal is that protection may be extended to animals other than game animals.

More effective control is now being exercised over the capture of wild birds, and the capture of and trade in these birds is not being permitted. Generally it may be said that much more is now being done to achieve the more effective conservation of wild life in South Africa than was done even five years ago.

\section{THE INTERNATIONAL UNION FOR THE PROTECTION OF NATURE}

Extracts from the Report of the Second Session of the General Assembly, held in Brussels, 18th-23rd October, 1950

M. van der Goes van Naters, Secretary of the Netherlands Provisional Nature Conservancy, spoke of the need for the Union to act as arbitrator in all international matters. Giving examples under four headings for the need for action, he said: "... a system must be established based on the following points :-

(a) Among the reports of the technical conference there are three concerned with frontier and international parks and in addition a résumé written by the Secretary-General.

The defence of the most untouched and the most valuable of these areas runs up against international obstacles. Here are some examples :- 